\title{
Pengaruh Pemberian Pupuk Limbah Tahu Terhadap Pertumbuhan Dan Hasil Tanaman Kacang Hijau (Vigna radiate $\mathrm{L}$. )
}

\author{
Zulkarnain Sangadji $^{1}$, Mira Herawati Soekamto ${ }^{2}$, Seljun Kayaru ${ }^{3}$ \\ Universitas Muhammadiyah Sorong \\ zulkarnainums1@gmail.com
}

\begin{abstract}
Abstrak
Tujuan dari penelitian ini adalah Untuk mengetahui pengaruh dan dosis pemberian pupuk limbah cair tahu terhadap pertumbuhan dan hasil tanaman kacang hijau. Metode yang digunakan dalam penelitian ini adalah eksperimen dengan memggunakan Rancangan Acak Kelompok dengan 4 perlakuan yang terdiri dari $\mathrm{S}_{0}$ (Tanpa Perlakuan), $S_{1}$ (15 ml Limbah Tahu/tanaman), $S_{2}$ (30 $\mathrm{ml}$ Limbah Tahu /tanaman), $\mathrm{S}_{3}$ (45ml limbah Tahu /tanaman) dengan 3 ulangan. Analisis data yang digunakan adalah analisis ragam yang dilanjutkan dengan uji Beda Nyata Jujur (BNJ) pada tingkat kepercayaannya $0,05 \%$. Hasil dari penelitian ini adalah Pemberian pupuk limbah cair berpengaruh nyata pada tinggi tanaman, jumlah daun, jumlah cabang produktif, jumlah biji per polong dan jumlah polong pertanaman, tetapi pada bobot 100 biji tidak menunjukkan pengaruh yang nyata. Perlakuan Dosis $45 \mathrm{ml} \mathrm{limbah}$ cair tahu/tanaman menghasilkan rata-rata tertinggi pada umur 1,2,3 dan 4 MST pada tinggi tanaman, jumlah daun, jumlah cabang produktif, jumlah biji per polong, jumlah polong per tanaman dan bobot 100 biji.
\end{abstract}

Kata Kunci : Pupuk, Limbah Tahu, Kacang Hijau

\section{PENDAHULAN}

Kacang hijau sebagai tanaman sumber utama protein nabati mempunyai prospek yang sangat besar dalam pengembangan budidayanya., karena tanaman yang masuk dalam kelas leguminose mempunyai kemampuan hidup yang cukup tinggi seperti tahan terhadap kekeringan. Meskipun mempunyai kelebihan tetapi fakta menunjukkan bahwa produksi kacang hijau masih cukup rendah terutama untuk wilayah kabupaten sorong. Data dari BPS, 2014 menunjukkan bahawa produksi kedelai di Papua barat sebesar 1.04 ton/ha, sedangkan untuk kabupaten sorong sebesar 1.05 ton/ha. Dibandingan dengan produksi nasional yaitu 1.18 ton/ha. Angka tersebut menunjukan bahwa produksi kacang hijau di Kabupaten sorong masih tergolong rendah. Rendahnya produksi kacang hijau bisa disebabkan berbagai factor diantaranya, teknik budidaya, faktor penurunan kesuburan tanah, serangan hama dan penyakit, kualitas benih rendah dan penggunaan varietas lokal yang berdaya tumbuh rendah.

Dalam meningkatkan produksi kacang hijau maka kendala-kendala ini perlu diperbaiki. Salah satu upaya yang dilakukan yaitu dengan meningkatkan kesuburan tanah bagi tanaman kacang hijau dengan melakukan pemupukan. Dalam meningkatkan 


\section{Median Volume 12 Nomor 2 Bulan}

produksi tanaman hijau, ketergantungan petani pada pemakaian pupuk anoragniak masih tinggi karena dianggap cepat memberikan respon pada peningkatan produksi tanaman, namun yang diketahui adalah dampak yang disebabkan oleh pemakaian pupuk tersebut pada penurunan kualitas tanahnya yang bisa mengakibatkan rendahnya kesubutan tanah. Menurut Herdiyanto dan Setiawan, 2015 menyatakan bahwa Pemakaian pupuk anorganik dalam jumlah berlebihan dan pengolahan tanah secara intensif akan dapat merusak kualitas tanah dan untuk mengurangi penggunaan pupuk anorganik tersebut maka dapat digunakan pupuk hayati dan pupuk organik.

Penggunaan pupuk organic pada lahan-lahan pertanian mempunyai manfaat yang sangat besar bagi keberlanjutan lahan. Selain menyediakan unsur hara makro dan mikro, pupuk organic juga sangat berperan pada perbaikan sifat fisik, kimia dan biologi (Hartatik dan Setyorini, 2012).

Pupuk organic berasal dari sisa-sisa tanaman ataupun limbah organik. Salah limbah organic yang dapat dimanfaatkan sebagai pupuk organic adalah limbah cair tahu. Air limbah tahu adalah air yang diperoleh dari hasil proses industri pembuatan tahu. Limbah cair tahu kaya akan bahan-bahan organic terutama mengandung protein yang tinggi yaitu mencapai 40\%-60\%, karbohidrat 25\%-505 dan kandungan lemak sebesar $10 \%$ dan kandungan ini jika semakin lama akan semakin meningkat volumenya (Sugiharto, 1994).

Pengembangan dari pengolahan limbah sagu menjadi pupuk organic mempunyai potensi yang besar. Hasil penelitian yang dilakukan oleh Lubis et al, 2015 menyatakan bahwa pemberian pupuk limbah cair tahu berpengaruh nyatmemberikan hasil yang nyata terhadap tinggi tanaman, jumlah daun, umur berbunga dan berat 100 biji pada tanaman kedelai. Sebagai upaya dalam meningkatakan produksi tanaman kacang hijau di Kabupaten Sorong, maka pemanfaatkan limbah cair tahu untuk pupuk organic sangat perlu dilakukan, namun untuk mengetahui seberapa besar pengaruh yang diberikan pada tanaman kacang hijau dalam mempengaruhi pertumbuhan dan produksi tanaman sejauh ini belum dilakukan sehingga sangat perlu dilakukan penelitian untuk mengetahui pengaruh pemberian pupuk limbah cair tahu pada tanaman kacang hijau di Kabupaten sorong yang menjadi daerah basis pengambangan pertanian.

\section{METODOLOGI PENELITIAN}

Lokasi pelaksanaan penelitian di Kelurahan Malawele Distrik Aimas Kabupaten Sorong yang berlangsung selama kurang lebih 4 bulan. Penelitian yang didesain dengan menggunakan Rancangan Acak Kelompok (RAK) dengan faktor tunggal. Faktor perlakuan terdiri dari dosis pupuk limbah cair tahu (gram) sebanyak 4 dosis yaitu: $\mathrm{S}_{0}$ $=$ Tanpa Perlakuan, $S_{1}=1.5 \mathrm{ml}$ Limbah Tahu/tanaman, $S_{2}=30 \mathrm{ml}$ Limbah Tahu /tanaman, $\mathrm{S}_{3}=45 \mathrm{ml}$ limbah Tahu /tanaman. Setiap kombinasi perlakukan 1 terdiri dari 3 ulangan.sehingga diperoleh 12 petak percobahan dengan ukuran $1 \mathrm{~m} \times 1 \mathrm{~m}$. Kompenen pertumbuhan dan produksi yang diamati dan ukur meliputi Tinggi tanaman, Jumlah daun, Jumlah cabang produktif, Umur berbunga, Jumlah polong per tanaman, Jumlah biji per polong, Bobot 1000 biji. Data yang diperoleh di analisis dengan analisis ragam 


\section{Median Volume 12 Nomor 2 Bulan}

Doi http://doi.org/md.v12i2.561

yang dilanjutkan uji beda nyata terkecil apabila hasil analisis menunjukkan pengaruh nyata dengan tingkat kepercayaan $0.05 \%$.

\section{HASIL DAN PEMBAHASAN}

\section{Tinggi Tanaman}

Pengukuran tinggi tanaman dilakukan untuk mengetahui pertumbuhan vegetatif pada suatu tanaman. Berdasarkan hasil sidik ragam tinggi tanaman yang di ukur menunjukkan bahwa pada perlakuan berbagai dosis pupuk limbah cair pada pengamatan minggu ke 1 dan 2 setelah tanam pada variabel tinggi tanaman tidak berbeda nyata, sedangkan hasil pada pengamatan 3 dan 4 MST pengaruh nyata. Nilai kenaikan pertumbuhan tinggi tanaman pada setiap minggu dapat dilihat pada tabel 1.

Tabel 1 Rata Tinggi Tanaman Kacang Hijau Pada Umur 2,4,6,8 MST

\begin{tabular}{ccccc}
\hline \multirow{2}{*}{ Perlakuan } & \multicolumn{5}{c}{ Minggu Ke- } \\
\cline { 2 - 5 } & 1 & 2 & 3 & 4 \\
\hline S0 & 9,00 & 24,66 & $44,11 \mathrm{a}$ & $87,00 \mathrm{a}$ \\
S1 & 6,89 & 26,89 & $51,11 \mathrm{a}$ & $84,66 \mathrm{a}$ \\
S2 & 7,89 & 24,77 & $51,00 \mathrm{a}$ & $87,22 \mathrm{a}$ \\
S3 & 9,00 & 27,11 & $54,55 \mathrm{~b}$ & $88,33 \mathrm{~b}$ \\
\hline BNJ & tn & tn & 7,83 & 3,39
\end{tabular}

Keterangan : Angka-angka yang diikuti oleh huruf yang tidak sama pada kolom $(a, b$, c) berarti berbeda nyata pada uji BNJ taraf uji $\alpha=0,05$

Tabel 1 menunjukkan bahwa hasil uji lanjut BNJ 0,05 dengan perlakuan pemberian limbah cair tahu pada berbagai dosis menunjukkan bahwa perlakuan S3, S1 dan S2 tidak berbada nyata tetapi terhadap perlakuan S3 menunjukkan pengaruh yang nyata. Gambaran Kenaikan pertumbuhan tinggi tanaman minggu ke-1, 2, 3 dan 4 dapat di lihat pada gambar 1 .

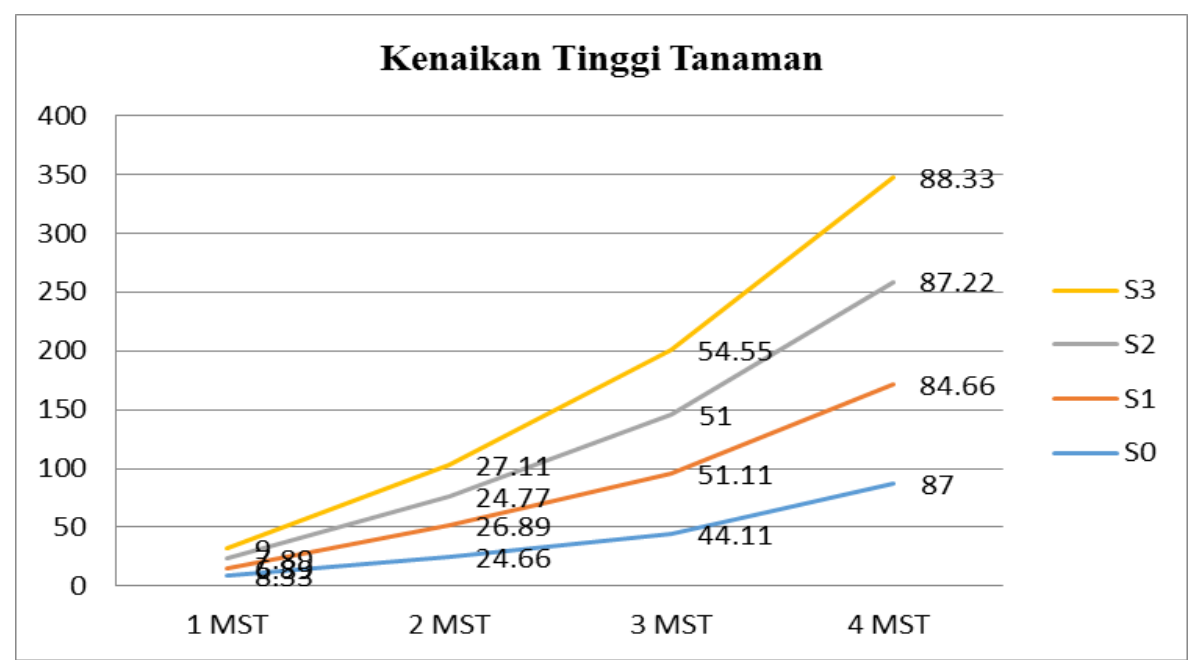

Gambar 1. Rata-rata Kenaikan Tinggi Tanaman 


\section{Median Volume 12 Nomor 2 Bulan}

Berdasarkan gambar 1. pertumbuhan tinggi tanaman dari perlakuan pemberian limbah cair tahu menggunakan dosis $45 \mathrm{ml} /$ pertanaman (S3) memberikan pertumbuhan tinggi tanaman yang terbaik dibanding perlakuan lainnya, sedangkan tanpa perlakuan (S0) dengan hasil terendah.

\section{Jumlah Daun}

Daun sebagai bagian dari organ tanaman yang berfungsi sebagai tempat berlangsungnya proses fotosintesis. Semakin banyak jumlah daun dalam satu tubuh tanaman memungkinkan pemerataan penerimaan cahaya oleh daun dan penyerapan hara menjadi lebih optimum. Berdasarkan hasil analisis sidik ragam jumlah daun yang di ukur menunjukkan bahwa pada perlakuan berbagai dosis pupuk limbah cair pada pengamatan minggu ke 1, 2, 3 dan 4 pengaruh terdapat tabel 2.

Tabel 2 rata-rata jumlah daun tanaman kacang hijau pada umur 1,2,3,4 MST

\begin{tabular}{ccccc}
\hline \multirow{2}{*}{ Perlakuan } & \multicolumn{5}{c}{ Minggu } \\
\cline { 2 - 5 } & 1 & 2 & 3 & 4 \\
\hline S0 & $11,00^{\mathrm{a}}$ & $38,22^{\mathrm{a}}$ & $67,54^{\mathrm{a}}$ & $85,67^{\mathrm{a}}$ \\
S1 & $13,55^{\mathrm{a}}$ & $36,11^{\mathrm{a}}$ & $70,11^{\mathrm{a}}$ & $89,33^{\mathrm{a}}$ \\
S2 & $14,00^{\mathrm{a}}$ & $40,55^{\mathrm{a}}$ & $71,23^{\mathrm{a}}$ & $90,44^{\mathrm{a}}$ \\
S3 & $17,00^{\mathrm{b}}$ & $49,22^{\mathrm{b}}$ & $74,55^{\mathrm{b}}$ & $93,94^{\mathrm{b}}$ \\
\hline BNJ & 4,39 & 9,31 & 5,16 & 7,27 \\
\hline
\end{tabular}

Keterangan : Angka-angka yang diikuti oleh huruf yang tidak sama pada kolom (a, $b$, c) berarti berbeda nyata pada uji BNJ taraf uji $\alpha=0,05$

Tabel 2 menunjukkan bahwa hasil uji lanjut BNJ 0,05 dengan perlakuan pemberian limbah cair tahu pada berbagai dosis terhadap jumlah daun menunjukkan bahwa perlakuan S3, S1 dan S2 tidak berbada nyata tetapi terhadap perlakuan S3 menunjukkan pengaruh yang nyata pada pengamatan minggu ke 1, 2, 3 dan 4 setelah tanam. Rata-rata kenaikan pertumbuhan jumlah daun pada setiap minggu pengukuran terlihat pada gambar 2 .

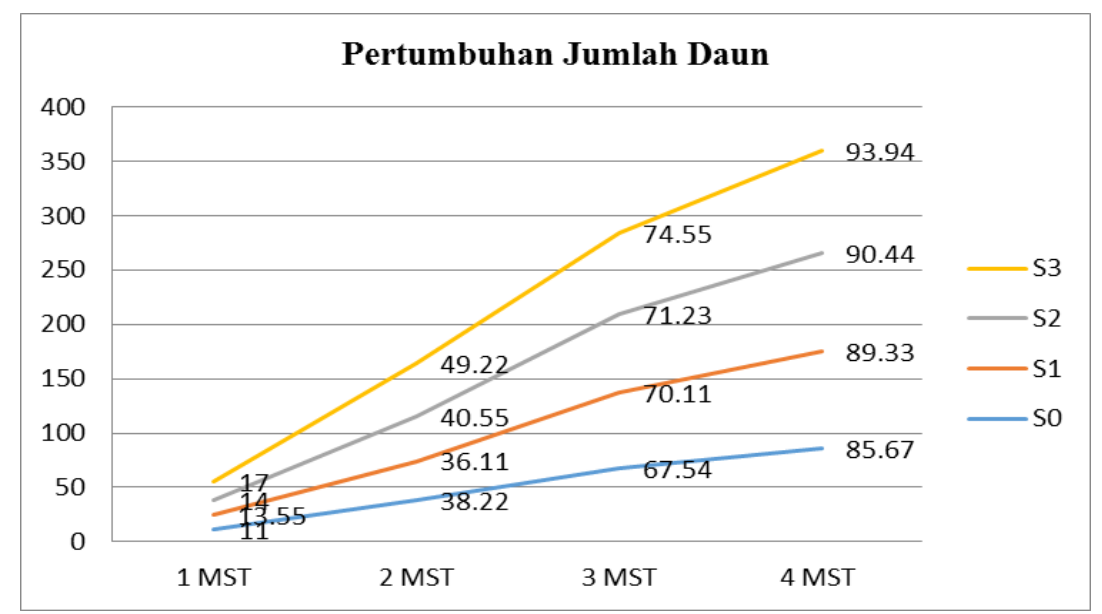

Gambar 2. Rata-rata Kenaikan Pertumbuhan Jumlah Daun Kacang Hijau 


\section{Median Volume 12 Nomor 2 Bulan}

Gambar 2 memperlihatkan pertumbuhan jumlah daun dari perlakuan pemberian pupuk limbah cair tahu $45 \mathrm{ml} /$ tanaman (S3) pada minggu ke-4 memberikan jumlah daun terbanyak. Tanpa perlakuan atau tanpa pemberian pupuk limbah cair tahu (S3) memberikan hasil pada jumlah daun yang paling rendah.

\section{Jumlah Cabang Produktif, Jumlah Biji Per Polong, Jumlah Polong Per Tanaman dan Bobot 100 Biji.}

Produktivitas suatu tanaman merupakan tujuan akhir dari kegiatan budidaya. Komponen hasil tanaman kacang hijau adalah jumlah cabang produktif, jumlah biji per polong, jumlah polong per tanaman dan bobot 100 biji.

Berdasarkan hasil tabel sidik ragam perlakuan pemberian berbagai dosis perlakuan limbah cair tahu menunjukkan hasil yang berbeda nyata pada hasil perhitungan data pada jumlah cabang produktif dan jumlah biji per polong serta jumlah polong pertanaman. Sedangkan pada bobot 100 biji tidak menunjukkan pengaruh yang nyata. Rata-rata hasil pengukuran untuk komponen hasil kacang hijau terdapat pada tabel 3.

Tabel 3. Rata-rata Jumlah Cabang Produktif, Jumlah Biji Per Polong, Jumlah Polong Per Tanaman dan Bobot 100 Biji

\begin{tabular}{ccccc}
\hline & \multicolumn{4}{c}{ Variabel } \\
\cline { 2 - 5 } Perlakuan & $\begin{array}{c}\text { Jumlah } \\
\text { Cabang } \\
\text { Produktif }\end{array}$ & $\begin{array}{c}\text { Jumlah Biji } \\
\text { Per Polong }\end{array}$ & $\begin{array}{c}\text { Jumlah Polong } \\
\text { Per Tanaman }\end{array}$ & $\begin{array}{c}\text { Bobot } 100 \\
\text { Biji }\end{array}$ \\
\hline S0 & $10,21^{\mathrm{a}}$ & $11,18^{\mathrm{a}}$ & $130,02^{\mathrm{a}}$ & 3,41 \\
S1 & $11,14^{\mathrm{a}}$ & $12,54^{\mathrm{a}}$ & $131,92^{\mathrm{a}}$ & 3,56 \\
S2 & $11,11^{\mathrm{a}}$ & $13,00^{\mathrm{a}}$ & $136,42^{\mathrm{a}}$ & 3,75 \\
S3 & $13,07^{\mathrm{b}}$ & $13,61^{\mathrm{b}}$ & $141,92^{\mathrm{b}}$ & 3,84 \\
\hline BNJ & 2,36 & 1,95 & 10,35 & tn \\
\hline Keterangan : Angka-angka yang diikuti oleh huruf yang tidak sama pada kolom $(\mathrm{a}, \mathrm{b}$,
\end{tabular}

c) berarti berbeda nyata pada uji BNJ taraf uji $\alpha=0,05$

Berdasarkan tabel 3 hasil uji lanjut dengan menggunkan BNJ 0,05 bahwa pada variabel jumlah cabang produktif, jumlah biji per polong dan jumlah polong per tanaman menunjukkan perlakuan S0, S1 dan S2 tidak berbeda nyata dan perlakuan S3 menunjukkan perbedaan nyata dengan perlakuan lainnnya. Gambaran variabel hasil dari tanaman kacang hijau dapat dilihat pada gambar 3. 


\section{Median Volume 12 Nomor 2 Bulan 2020}

Doi http://doi.org/md.v12i2.561

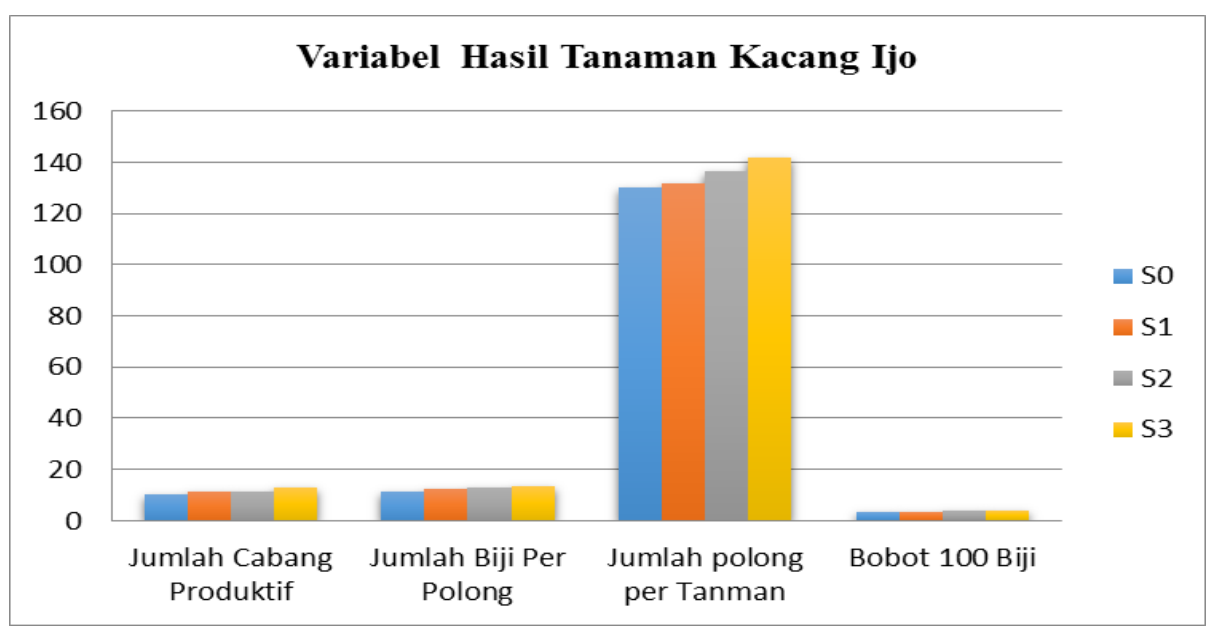

Gambar 3. Variabel Hasil Tanaman Kacang Hijau

Berdasarkan gambar 3 memperlihatkan pengaruh pemberian pupuk limbah cair tahu pada variabel cabang produktif memberikan hasil tertinggi pada perlakuan S3 ( 45 ml/tanaman) yaitu sebesar 13,07 sedangkan terendah berada pada perlakuan S0 (tanpa perlakuan) yaitu sebesar 10,21. Pada jumlah biji per polong menunjukkan jumlah terbesar berada pada perlakuan S3 (45 ml/tanaman) sebesar 13, 61 dan terkecil pada S0 (tanpa perlakuan) yaitu 11,18 . Untuk variabel jumlah polong per tanaman menunjukkan perlakuan S3 jug memberikan hasil terbanyak yaitu 141,92 dan terendah pada S0 (tanpa perlakuan) yaitu 130,02 dan variabel bobot 100 biji juga menunjukkan perlakuan S3 memberikan hasilll yang terbesar yaitu 3,84 gr dan terendah berada pada tanpa perlakuan (S0) yaitu sebesar 3,41 gr.

\section{Pembahasan}

Berdasarkan hasil penelitian pada perlakuan pemberian limbah cair tahu menunjukkan pengaruh yang nyata pada variabel tinggi tanaman, jumlah cabang produktif, jumlah daun, jumlah biji per polong dan jumlah polong per tanaman. Sedangkan pada bobot 100 biji tidak menunjukkan pengaruh tidak nyata/tidak berbeda nyata.

Hasil rata-rata terbesar pada tinggi tanaman pada pengamatan minggu ke-4 berada pada perlakuan S3 yaitu $88,43 \mathrm{~cm}$ dengan jumlah dosis pemberian sebesar 45 $\mathrm{ml} /$ tanaman pupuk limbah cair tahu dan terendah pada tanpa perlakuan atau tanpa pemberian pupuk limbah cair tahu yaitu sebesar $87,00 \mathrm{~cm}$. Hal ini menunjukkan bahwa dengan pemberian pupuk cair limbah tahu dapat meningkatkan variabel pertumbuhan pada tanaman khusunya tinggi tanaman kacang hijau. Hal ini diduga karena limbah tahu memiliki kandungan protein yang lebih tinggi yaitu 8,66 \%,diikuti kandungan lemak $3,79 \%$, air 5,63\% dan abu 1,21\%. Komposisi kandungan ini menjadikan ampas tahu dapat dugunakan sebagai bahan pakan ternak.

Adanya peningkatan pemberian dosis dari S1 (15 ml/tanaman) hingga S3 (45 $\mathrm{ml} /$ tanaman) menunjukkan kenaikan yang signifikan sehingga dapat terlihat adanya kekurangan pemenuhan unsur hara bagi tanaman dari setiap perlakuan, sehingga setiap 


\section{Median Volume 12 Nomor 2 Bulan}

kenaikan dosis pupuk cair limbah tahu, terjadi juga kenaikan pertumbuhan tinggi tanaman kacang hijau mulai dari perlakuan $15 \mathrm{ml}$ pupuk limbah cair tahu/tanaman hingga $45 \mathrm{ml}$ pupuk limbah cair tahu/tanaman yang mempunyai tinggi tanaman yang terbesar dari semua perlakuan. Menurut lubis et al, 2015 menjelaskan pada hasil penelitian yang dilakukan pada tanaman kedelai dari pemberian pupuk limbah cair tahu hingga 5 MST mengalami peningkatan seiring dengan penambahan dosis yang ditunjukkan dengan hubungan linear yang positif. .

Begitu juga pada variabel pertumbuhan jumlah daun dimana hasil sidik ragam menunjukkan setiap perlakuan berpengaruh nyata yang dibuktikan dengan hasil uji lanjut, yang menunjukkan adanya perbedaan nyata pada perlakuan S3 dengan yang lainnya. Hal ini diduga karena pada perlakuan S3, ketersediaan unsur hara lebih banyak terpenuhi untuk kebutuhan pertumbuhan jumlah daun disebabkan dosis yang lebih tinggi dibanding perlakuan lainnnya karena semakin tinggi dosis maka semakin tinggi pula kandungan unsur hara yang terdapat di dalam pupuk limbah cair tahu terutama pada nitrogen yang mempunyai peran penting pada pertumbuhan vegetatif tanaman. Menurut Sugiharto (1994), yang menyatakan kandungan bahan organik dalam limbah tahu berupa karbohidrat, protein dan lemak dalam jumlah yang cukup besar. Pendapat lain yang dikemukakan oleh Rosalina, 2008 menyatakan bahwa Dalam limbah tahu terdapat senyawa $\mathrm{N}$ dalam bentuk N-organik, N-nitrit $\left(\mathrm{NO}_{2}{ }^{-}\right), \mathrm{N}$-nitrat $\left(\mathrm{NO}_{3}{ }^{-}\right), \mathrm{N}$ ammonium $\left(\mathrm{NH}_{4}{ }^{+}\right)$. Senyawa nitrat $\left(\mathrm{NO}_{3}{ }^{-}\right)$yang langsung menjadi untuk yang tersedia dan dapat diserap tanaman untuk pertumbuhan. Sedangkan ammonium $\left(\mathrm{NH}_{4}{ }^{+}\right)$dan ( $\mathrm{NO}_{2}^{-}$) akan diubah melalui proses nitrifikasi yang berlangsung dengan bantuan bakteri pengikat nitrogen senyawa nitrat $\left(\mathrm{NO}_{3}{ }^{-}\right)$. Limbah tahu memiliki kandungan organik tinggi.

Hasil analisi ragam pada variabel hasil menunjukkan pengaruh yang nyata pada jumlah cabang produktif, jumlah biji per polong dan jumlah polong pertanaman. Namun untuk bobot 100 biji tidak menunjukkan pengaruh yang nyata tetapi bobot 100 Biji tertinggi berada pada perlakuan S3. Hal ini diduga karena kandungan lain dari limbah air tahu bukan hanya mengandung protein tetapi juga karbohidrat, lemak yang akan diuraikan menghasilkan unsur-unsur antara lain $\mathrm{P}, \mathrm{K}, \mathrm{Ca}, \mathrm{Fe}, \mathrm{Cu}, \mathrm{C}, \mathrm{H}, \mathrm{O}, \mathrm{S}$ yang mempunyai peran penting dalam pertumbuhan generatif tanaman serta berperan penting dalam proses metabolisme tanaman.

Menurut Indahwati (2008), Kandungan satu liter limbah cair tahu mengandung protein 7, $1253 \mathrm{mg}$, pati $7 \mathrm{mg}$, K 0,5945 mg, Ca 0, $2247 \mathrm{mg}$, Fe 0,0024 mg, Na 1,3535 mg, dan Vitamin B1 0, $20 \mathrm{mg}$. Menurut pendapat Makiyah (2013) hasil analisis N, P, dan K pada pupuk limbah cair tahu memiliki kandungan yang tinggi sehingga dapat memenuhi unsur hara yang bersifat makro bagi tanaman. Menurut Munawar 2011 yang menyatakan unsur $\mathrm{N}, \mathrm{P}$ dan $\mathrm{K}$ terlibat dalam reaksi biosintesis di dalam tanah seperti fotosintesis, sintesis protein dan hampir semua aspek pertumbuhan dan metabolisme di dalam tanaman, dari pertumbuhan tanaman muda sampai pembentukan bunga dan biji serta pemasakannya. Hasil penelitian Sagrim dan Soekamto, 2019 


\section{Median Volume 12 Nomor 2 Bulan}

bahwa perlakuan media tanam dengan limbah tahu memberikan hasil yang paling baik dibandingkan dengan media tanam lainnnya. Hasl ini membuktikan limbah tahu mempunyai potensi yang besar dalam pemanfaatannya baik sebagai pupuk atauppun media tanam bagi tanaman.

\section{PENUTUP}

Berdasarkan hasil penelitian yang telah dilakukan maka dapat disimpulkan bahwa:

1. Pemberian pupuk limbah cair memberikan pengaruh yang nyata pada tinggi tanaman, jumlah cabang produktif, jumlah daun, jumlah biji per polong dan jumlah polong pertanaman, tetapi pada bobot 100 biji tidak menunjukkan pengaruh yang nyata.

2. Perlakuan Dosis $45 \mathrm{ml}$ limbah cair tahu/tanaman menghasilkan rata-rata tertinggi pada umur 1,2,3 dan 4 MST pada tinggi tanaman, jumlah cabang produktif, jumlah daun, jumlah biji per polong, jumlah polong per tanaman dan bobot 100 biji.

\section{DAFTAR PUSTAKA}

Andrianto, T T. dan Indarto, N., 2004. Budidaya dan Analisis Tani Kedelai, Kacang Hijau, Kacang Panjang. Absolut. Yogyakarta.

Hartatik, W., \& Setyorini, D. (2012). Pemanfaatan pupuk organik untuk meningkatkan kesuburan tanah dan kualitas tanaman. Badan Penelitian Litbang Pertanian Balai Penelitian Tanah. Bogor.

Herdiyanto, D., \& Setiawan, A. (2015). Upaya peningkatan kualitas tanah melalui sosialisasi pupuk hayati, pupuk organik, dan olah tanah konservasi di Desa Sukamanah dan Desa Nanggerang Kecamatan Cigalontang Kabupaten Tasikmalaya. Dharmakarya, 4(1).

Indahwati. 2008. Pengaruh Pemberian Limbah Cair Tahu terhadap Pertumbuhan Vegetatif Cabai Merah (Capsicum Annuum. L) Secara Hidroponik dengan Metode Kultur Serabut Kelapa. Skripsi . Malang: Program Studi Pendidikan Biologi Jurusan Pendidikan Matematika Dan Ilmu Pengetahuan Alam Fakultas Keguruan dan Ilmu Pendidikan Universitas Muhammadiyah.

Lubis, E., \& Srg, M. A. H. (2015). Pengaruh Pemberian Limbah Cair Tahu Dan Pupuk Urea Terhadap Pertumbuhan Dan Produksi Tanaman Kedelai (Glycine max L.(Merill). AGRIUM: Jurnal Ilmu Pertanian, 18(1).

Makiyah, Mujiatul. 2013. Analisis kadar N, P dan K Pada Pupuk Cair Limbah Tahu Dengan Penambahan Tanaman Matahari Meksiko (Thitonia diversivolia). Skripsi Sarjana. Fakultas Matematika Dan Ilmu Pengetahuan Alam. Universitas Negeri Semarang

Munawar, Ali, 2011. Kesuburan Tanah dan Nutrisi Tanaman. IPB Press

Pohan, N. 2008. Pengolahan Limbah Cair Tahu dengan Proses Biofilter sAerobik. Skripsi. Medan: Sekolah Pascasarjana Universitas Sumatera Utara 


\section{Median Volume 12 Nomor 2 Bulan}

Purnomo, J. (2008). Pengaruh Pupuk NPK Majemuk terhadap Hasil Padi Varietas

Ciherang dan Sifat Kimia Tanah Inceptisol Bogor. In Prosiding Seminar Nasional dan Dialog Sumberdaya Lahan Pertanian. Balittanah. Bogor.

Purwono dan R. Hartono,. 2012. Seri Agribisnis : Kacang Hijau. Penerbit Penebar Swadaya; Jakarta.

Rosallina, Nur. 2008. Pengaruh Konsentrasi dan Frekuensi Penyiraman Air Limbah Tempe sebagai Pupuk Organik terhadap Pertumbuhan dan Hasil Tomat

Agrotropika Hayat Vol. 3. No. 3 Agustus 2016 Page 52 (Lycopersicum esculentum Mill.). skripisi. Malang: Jurusan Biologi Universitas Islam Negeri Malang.

Rukmana. R., 2000. Kacang Hijau Budidaya dan Pasca Panen. Kanisius. Yogyakarta.

Sagrim, I., \& Soekamto, M. H. (2019). Pembibitan Tanaman Pinang (Areca catechu) Dengan Menggunakan Berbagai Media Tanam. Median: Jurnal Ilmu Ilmu Eksakta, 10(2), 28-36.

Sarwono 2004. Sifat Limbah Tahu. Jakarta

Setiawan, 2009. Pengolahan Limbah Cair Tahu. 8 http://www. anakagronomy. Com /2013/ 01/ laporan-praktikumpengaruh-limbah. html.Diakses Pada Tanggal 21 Maret 2013

Sugiharto. 1994. Dasar-Dasar Pengolahan Air Limbah. Jakarta: Penerbit Universitas Indonesia. 